\title{
Seasonal variation in pituitary-gonadal function in free-ranging impala (Aepyceros melampus)
}

\author{
J. L. Brown ${ }^{1}$, D. E. Wildt ${ }^{2}$, J. R. Raath ${ }^{3}$, V. de Vos ${ }^{3}$, D. L. Janssen ${ }^{4}$, \\ S. B. Citino ${ }^{5}$ J. G. Howard ${ }^{2}$ and M. Bush ${ }^{2}$
}

${ }^{1}$ Department of Obstetrics and Gynecology, Uniformed Services University of the Health Sciences,

Bethesda, MD 20814, USA; ${ }^{2}$ Department of Animal Health, National Zoological Park, Smithsonian Institution, Washington, DC 20008, USA; ${ }^{3}$ Kruger National Park, Skukuza 1350 , Republic of South Africa; ${ }^{4}$ Department of Veterinary Services, San Diego Zoological Society, San Diego, CA 92112, USA; and ${ }^{5}$ Miami Metro Zoo, Miami, FL 33177, USA

\begin{abstract}
Summary. Blood, testicular biopsies and electroejaculates were collected from adult male impala, free-ranging in the Kruger National Park (Republic of South Africa), during the breeding (rut; April-May) and nonbreeding (September-October) seasons. Blood samples were collected at 5-min intervals for $120 \mathrm{~min}$ from anaesthetized males ( $n=7$ impala/group) treated intravenously with saline, gonadotrophin-releasing hormone (GnRH: $1 \mu \mathrm{g} / \mathrm{kg}$ body weight) or human chorionic gonadotrophin (hCG: 10 or $30 \mathrm{iu} / \mathrm{kg}$ ). Semen was collected from six more animals during the breeding season and 12 animals during the nonbreeding season using a standardized electroejaculation protocol. Ejaculates obtained during the nonbreeding season were of inferior quality to those collected during the breeding season, and were characterized by lower sperm concentrations, poorer sperm motility and more morphologically abnormal sperm forms. Within season, there were no differences in testosterone secretion between the two hCG doses, and these responses were similar to those observed after GnRH, but during the rut, testosterone secretion stimulated by both GnRH and hCG was approximately nine times greater than during the nonbreeding season. This seasonal increase in testosterone production was associated with a doubling in testicular volume and concentrations of luteinizing hormone (LH) receptors. Although concentrations of testicular follicle-stimulating hormone (FSH) receptors were similar between seasons, receptor content increased during rut as a result of increased testicular volume. In contrast to testosterone secretion, basal LH and FSH secretions were unaffected by season and $\mathrm{GnRH}$-induced gonadotrophin secretion was reduced during rut. These data indicate that: (i) seminal quality in free-ranging impala undergoes seasonal changes coincident with alterations in testicular steroidogenic activity, and (ii) the increased testosterone secretion observed during rut is associated with increased testicular sensitivity to $\mathrm{LH}$ (via increased gonadotrophin receptors) rather than to increased circulating gonadotrophin concentrations or pituitary responsiveness to GnRH.
\end{abstract}

Keywords: impala; LH; FSH; testosterone; testis; receptors

\section{Introduction}

The impala (Aepyceros melampus) is an abundant antelope species inhabiting the woodlands and savannahs of eastern, central and southern Africa. Near the equator, reproduction is not seasonal and births occur throughout the year (Kayanja, 1969; Jarman \& Jarman, 1974). However, most

\footnotetext{
${ }^{*}$ Reprint requests.
} 
breeding activity in southern Africa takes place during a 'rut' of 3-5 weeks following the November-February rainy season (Fairall, 1972; Murray, 1982). During the remainder of the year, male impala are found in loose coalitions with other males (bachelor herds) or in herds of mixed sex. Male activity intensifies during rut and is characterized by marked increases in intermale aggression and territorial defence (Fairall, 1972; Murray, 1982). Only one or, at most, two adult males are associated with a breeding herd at any given time during rut (Fairall, 1972; Murray, 1982). Most of the copulatory activity is performed by these dominant, territorial males (Murray, 1982), which are known to produce greater circulating testosterone concentrations than bachelor impala (Bramley \& Neaves, 1972; Illius et al., 1983), suggesting that there is a relationship between social status and endocrine function in this species. The impact of season on gonadal and endocrine activity has not been studied extensively in impala.

One of our long-range goals is to establish a reproductive and endocrine database for a range of free-living African wildlife species. This information is important from a comparative perspective and may be helpful for managing both captive and free-living populations. The present study was of a presumably homogeneous impala population, free-ranging in the Kruger National Park in southern Africa. Our objectives were to assess the influence of season on male reproductive function by evaluating changes in (i) seminal characteristics, (ii) the responsiveness of the pituitary and testis to exogenous hormonal stimulation (gonadotrophin-releasing hormone (GnRH) and human chorionic gonadotrophin (hCG)) and (iii) testicular sensitivity to gonadotrophins through analyses of luteinizing hormone (LH) and follicle-stimulating hormone (FSH) receptors.

\section{Materials and Methods}

Animals and experimental protocol. Adult male impala, free-ranging in the Kruger National Park, Republic of South Africa ( $\sim 25^{\circ} \mathrm{S}$ latitude) were evaluated between 22 September and 12 October 1988 (nonbreeding season) and 29 April and 4 May 1989 (breeding season: rut). During rut, all evaluated males were associated with female breeding herds. During the nonbreeding season males were associated with both mixed and bachelor herds. Impala were approached by vehicle and anaesthetized with a projectile dart containing $3 \mathrm{mg}$ etorphine- $\mathrm{HCl}$ (M99: Reckitt and Coleman, Hull, UK) and $10 \mathrm{mg}$ xylazine (Rompun: Bayer UK, Bury St Edmunds, Suffolk, UK). Within 10-30 min, a jugular catheter (16 gauge, $5 \mathrm{~cm}$; Deseret, Sandy, UT, USA) was inserted and blood samples were collected at 5-min intervals for $120 \mathrm{~min}$. During each season, seven animals were each given saline $(3 \mathrm{ml}), \mathrm{GnRH}(1 \mu \mathrm{g} / \mathrm{kg}$ body weight; Cystorelin, Abbott Labs, Chicago, IL, USA) or hCG (10 or $30 \mathrm{iu} / \mathrm{kg}$; Sigma, St Louis, MO, USA) i.v. after the third blood sample. The length and width of each testis were measured using vernier calipers and testicular volumes were estimated using the formula for calculating the volume of a prolate sphere (Oberg \& Jones, 1969). Scrotal circumference at the widest point of the scrotum was measured using a flexible cloth tape. After the last blood sample had been taken the scrotal area was shaved and $\sim 350 \mathrm{mg}$ of testicular parenchyma removed using an incisional biopsy technique under sterile conditions (Burke, 1986). The biopsy sample was frozen immediately on dry ice and stored at $-79^{\circ} \mathrm{C}$ until assayed for gonadotrophin receptors. Following the biopsy, all animals received an injection of longacting penicillin. Anaesthesia was reversed with an i.v. injection of $8 \mathrm{mg}$ diprenorphine-HCl (Revivon: Reckitt and Coleman, Hull, UK) and the animals were monitored until ataxia was no longer evident.

All serum samples were irradiated with $60 \mathrm{kGy}$ of ${ }^{60} \mathrm{Co}$ (Iso-Ster, Kempton Park, RSA) before export to the USA to comply with US Department of Agriculture (USDA) regulations. A prestudy trial demonstrated that irradiation did not affect $(P>0.05)$ the concentrations of serum steroid or protein hormones in rat or sheep serum, but did reduce $(P>0.05)$ gonadotrophin receptor binding in rat testis by $\sim 33 \%$ (J. L. Brown, unpublished data). Therefore. testicular biopsy samples were not irradiated and all radioreceptor assays were conducted in quarantine facilities at the USDA Plum Island Animal Disease Center (Long Island, NY).

Semen collection. Semen was collected from all six anaesthetized impala during the breeding season and 12 of 14 impala during the nonbreeding season; two of the 14 males electroejaculated during the nonbreeding season produced aspermic ejaculates. A standardized electroejaculation regimen (Howard et al., 1983; Wildt et al., 1983) was used with the following modifications. The rectal probe was $40 \mathrm{~cm}$ long and $2.7 \mathrm{~cm}$ in diameter with three longitudinal electrodes. The regimented sequence consisted of 80 incremental stimuli given in three series. Series I and II consisted of 30 stimuli each, divided into three sets of ten stimuli at 3,4 and $5 \mathrm{~V}$ (Series I) and 4, 5 and $6 \mathrm{~V}$ (Series II). Series III consisted of ten stimuli each at 5 and $6 \mathrm{~V}$. Semen from all three series was combined and evaluated as previously described (Howard et al., 1983; Wildt et al., 1983). Briefly, semen was evaluated qualitatively for percentage motility and progressive status (speed of forward progression based on a scale of 0 , no movement to 5 , rapid progressive motility) using phase-contrast microscopy $(200 \times)$. Gross morphological assessments of glutaraldehyde-fixed sperm were made using phase-contrast microscopy $(\times 1000$ under oil $)$. 
Radioimmunoassays. The heterologous LH assay was developed in this laboratory and used NIH-LH-S18 as the reference preparation and an anti-ovine LH (NIH-LH-S18) antiserum. The custom antiserum was produced by Duncroft, Inc. (Lovettsville, VA, USA) and used at a final dilution of 1:400000. The complete description and validation of this antiserum (PKC-23IA) has been published (Brown et al., 1991). The sensitivity, calculated as $90 \%$ of maximum binding, was $0.07 \mathrm{ng} / \mathrm{ml}$. When $0.06,0.13,0.25,0.50,1.00$ and $2.00 \mathrm{ng}$ ovine $\mathrm{LH}$ were added to $50 \mu 1$ serum, $0.06,0.13,0.24,0.55,1.22$ and $2.05 \mathrm{ng}$ were recovered after subtracting endogenously measured hormone $(y=1.05 x+0.02 ; r=0.99)$. Serial dilutions of impala serum were parallel to the standard curve. Inter- and intra-assay coefficients of variation were 7.8 and $6.7 \%$, respectively.

Serum FSH was measured using a radioimmunoassay previously validated for sheep serum (Brown et al., 1987) with NIADDK-FSH-S16 serving as the reference preparation. After adding 1.25, 2.5, 5, 10, 20,40 and $80 \mathrm{ng}$ ovine FSH to $50 \mu \mathrm{l}$ serum and subtracting endogenous ligand, 1.42, 2.33,5.25, 10.50, 20.22, 39.00 and $80 \cdot 19 \mathrm{ng}$ was recovered $(y=0.99 x+0.11 ; r=0.99)$. Assay sensitivity was $5 \mathrm{ng} / \mathrm{ml}$. Serial dilutions of impala serum were parallel to the standard curve. Inter- and intra-assay coefficients of variation were 6.5 and $5.9 \%$, respectively.

Serum testosterone was measured in unextracted serum using a ${ }^{125}$ I radioimmunoassay kit (ICN, Carson, CA, USA). To improve the parallelism between serum pool dilutions and standards, each standard curve was prepared using charcoal-stripped impala serum. Upon adding $0 \cdot 1,0 \cdot 25,0 \cdot 5,1 \cdot 0,2 \cdot 5$ and $5 \cdot 0 \mathrm{ng}$ testosterone to $25 \mu \mathrm{l}$ serum, and after subtracting endogenous hormone, $0 \cdot 11,0 \cdot 25,0 \cdot 45,1 \cdot 39,3 \cdot 11$ and $4.97 \mathrm{ng}$ was recovered $(y=1 \cdot 02 x+0 \cdot 13$; $r=0.98$ ). Serial dilutions of impala serum were parallel to the standard curve. The assay sensitivity was $0.05 \mathrm{ng} / \mathrm{ml}$, and the inter- and intra-assay coefficients of variation were $7 \cdot 4$ and $6.8 \%$, respectively.

Radioreceptor assays. Highly purified hCG (9800 iu/mg; ICN, Carson, CA, USA) and ovine FSH (LER-1976-A2) were used as labelled ligands, and crude hCG (3225 iu/mg; Sigma) and ovine FSH (NIADDK-FSH-S16) served as unlabelled ligands in the LH and FSH receptor assays, respectively. Specific activities of the labelled hCG and FSH were $\sim 30$ and $5 \mu \mathrm{Ci} / \mu \mathrm{g}$, respectively (as determined by self-displacement analyses). LH and FSH receptors were measured in testicular homogenates by a standard curve technique described for sheep and rat testis (Brown et al., 1987; Brown \& Chakraborty, 1988) using a pool of partially purified rat testis membranes as the reference preparation. Biopsy samples were homogenized in assay buffer containing glycerol (25mM Tris- $\mathrm{HCl}, 3 \cdot 8 \mathrm{mM}-\mathrm{NaN}_{3}$, $10 \mathrm{mM}-\mathrm{MgCl}_{2}, 0 \cdot 1 \%$ bovine serum albumin and $10 \%$ glycerol, $\mathrm{pH} 7.4$ at $20^{\circ} \mathrm{C}$ ) to a concentration of $200 \mathrm{mg} / \mathrm{ml}$. Each standard curve was constructed by incubating 200000 c.p.m. labelled hormone (in the presence or absence of excess unlabelled hormone for determination of nonspecific binding) with $1.41-120 \mathrm{mg}$ rat testis membranes (fresh tissue equivalent)/tube. Triplicate $100 \mu \mathrm{l}$ aliquots of impala testis homogenate were analysed and compared with the standard curve. Assays were incubated for $16 \mathrm{~h}$ at $20^{\circ} \mathrm{C}$ and the reaction was stopped by addition of $3 \mathrm{ml}$ cold rinse buffer (10mM Tris- $\mathrm{HCl}, 0.154 \mathrm{M}-\mathrm{NaCl}, 3.8 \mathrm{~mm}-\mathrm{NaN}_{3}, \mathrm{pH} 7.4$ at $\left.4^{\circ} \mathrm{C}\right)$ and centrifugation at $3500 \mathrm{~g}$ for $30 \mathrm{~min}$. Scatchard analysis of saturation curves was used to estimate the receptor concentrations of the rat testis standard pool. For both the LH and FSH receptor assays, parallelism was obtained between serial dilutions of rat and impala testis homogenate pools, suggesting both receptor populations possessed similar affinities for their respective labelled ligands.

Statistical analysis. Gonadotrophin and testosterone responses to GnRH and testosterone responses to hCG were evaluated as peak height and net area under the response curves. Endocrine and seminal mean data were analysed by analysis of variance and differences among treatment groups were determined using Student's $t$ tests or Duncan's New Multiple Range tests. Data are presented as means \pm s.e.m.

\section{Results}

\section{Serum hormones}

Mean basal LH concentrations in saline-treated control males were similar $(P>0.05)$ in the breeding and nonbreeding seasons (Fig. 1a). There was no evidence of pulsatile secretion during the 2-h bleeding period in either season. GnRH elicited an increase in serum LH in all animals that was evident within 10-15 min of injection. Peak LH concentrations were observed within $\sim 100$ min after the challenge and in neither season did $\mathrm{LH}$ concentrations return to baseline by the end of bleeding period. During the nonbreeding season, the total amount of LH secreted after GnRH was more than three times greater $(P<0.05)$ than that measured during the breeding season.

Mean pretreatment testosterone concentrations in saline-treated males were higher $(P<0.05)$ during the breeding than the nonbreeding season $(1.89 \pm 0.40 \mathrm{vs} .0 .82 \pm 0.24 \mathrm{ng} / \mathrm{ml})$ (Fig. 1b). However, because of a $\sim 50 \%$ decline in circulating testosterone in impala during rut, overall mean basal concentrations were similar $(P>0.05)$ in the two seasons $(0.86 \pm 0.33 \mathrm{vs.} 0.84 \pm 0.21 \mathrm{ng} / \mathrm{ml})$. Overall, pretreatment concentrations of testosterone for all groups were higher $(P<0.05)$ during the breeding $(3.10 \pm 0.40 \mathrm{ng} / \mathrm{ml})$ than the nonbreeding $(0.96 \pm 0.25 \mathrm{ng} / \mathrm{ml})$ season. Doses of 10 

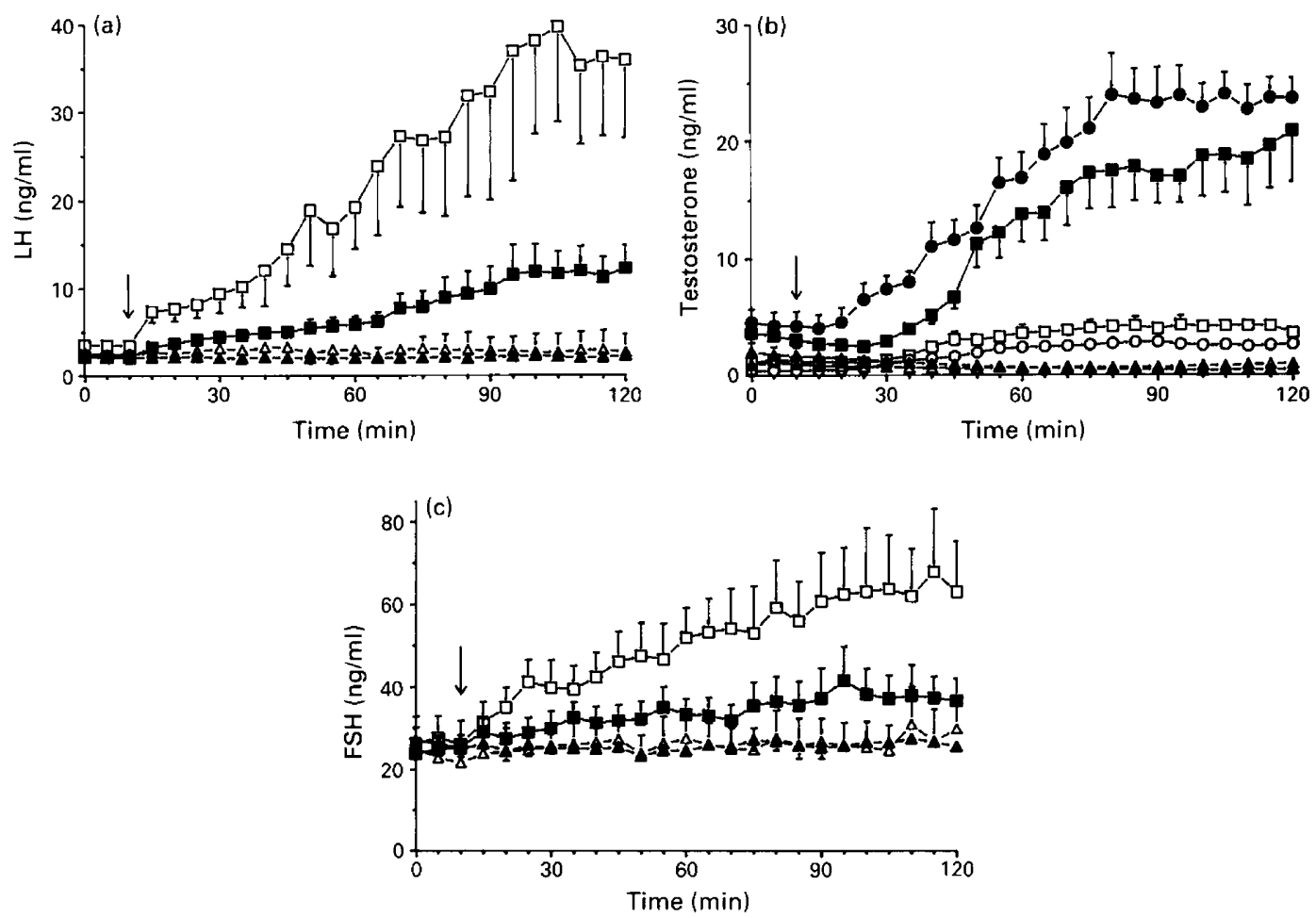

Fig. 1. Serum concentrations of (a) luteinizing hormone (LH); (b) testosterone; and (c) folliclestimulating hormone (FSH) in adult male impala administered gonadotrophin-releasing hormone $(\boldsymbol{\square}, \square)$ human chorionic gonadotrophin $(\boldsymbol{\Theta}, O)$ or saline $(\boldsymbol{\Delta}, \Delta)$ i.v. during the breeding (closed symbols) or nonbreeding (open symbols) season. Arrow designates time of treatment administration. Data are means \pm s.e.m.

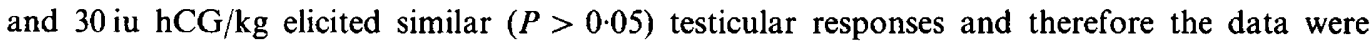
pooled. Secretion of testosterone after GnRH or hCG was greater $(P<0.05)$ during the breeding season. Concentrations increased three times over baseline in nonbreeding season males compared with a $\sim 25$-fold increase for both treatments during rut (Fig. 1b). Within season, the mean testosterone response to hCG was not different $(P>0.05)$ from that observed after GnRH. Pulsatile testosterone secretion was not observed in saline-treated animals during any season.

Mean basal FSH secretion was similar $(P>0.05)$ in the breeding and nonbreeding seasons (Fig. 1c), but the FSH response to GnRH during the nonbreeding season was nearly twice that observed during rut $(P<0.05)$.

\section{Testicular analyses}

Combined testicular volume $\left(133.5 \pm 6.6 \mathrm{~cm}^{3}\right.$, breeding season; $56.7 \pm 2.0 \mathrm{~cm}^{3}$, nonbreeding season) and scrotal circumference $(21 \cdot 2 \pm 0.3 \mathrm{~cm}$, breeding season; $16.6 \pm 0.2 \mathrm{~cm}$, nonbreeding season) were greater $(P<0.05)$ during the breeding than the nonbreeding season.

Concentrations of testicular LH and FSH receptors were unaffected $(P>0.05)$ by saline, GnRH or hCG treatment or the electroejaculation procedure; the data presented in Table 1 were therefore pooled among these groups. LH receptor concentrations were doubled $(P<0 \cdot 05)$ during rut compared to the nonbreeding season. In contrast, FSH receptor concentrations were similar $(P>0.05)$ between seasons. 
Table 1. Concentrations of testicular luteinizing hormone ( $\mathrm{LH})$ and follicle-stimulating hormone (FSH) receptors in free-ranging impala during the breeding and nonbreeding seasons in the Kruger National Park, Republic of South Africa

\begin{tabular}{lccc}
\hline & $n$ & $\begin{array}{c}\text { LH receptors } \\
\text { (fmol/mg tissue) }\end{array}$ & $\begin{array}{c}\text { FSH receptors } \\
\text { (fmol/mg tissue) }\end{array}$ \\
\hline Breeding season & 34 & $0.44 \pm 0.02^{\mathrm{a}}$ & $18.5 \pm 1 \cdot 8^{\mathrm{a}}$ \\
Nonbreeding season & 40 & $0.22 \pm 0.02^{\mathrm{b}}$ & $22.0 \pm 0.8^{\mathrm{a}}$ \\
\hline
\end{tabular}

a,b Values within columns with different superscripts are different $(P<0 \cdot 05)$. Data are means \pm s.e.m.

\section{Seminal characteristics}

Mean ejaculatory volume and sperm motility status were similar $(P>0.05)$ in males evaluated during the breeding and nonbreeding seasons (Table 2). In contrast, sperm concentration and motility were reduced $(P<0.05)$ and the proportions of sperm abnormalities were greater $(P<0.05)$ in ejaculates collected during the nonbreeding than in the breeding season. These ejaculates contained a higher $(P<0.05)$ percentage of spermatozoa with acrosomal abnormalities (including a knobbed acrosome and loose acrosomal cap defect), proximal cytoplasmic droplets and bent midpieces with droplets.

Table 2. Ejaculate traits and sperm characteristics of free-ranging adult male impala during the breeding and nonbreeding seasons in the Kruger National Park, Republic of South Africa

\begin{tabular}{|c|c|c|}
\hline & $\begin{array}{l}\text { Breeding season } \\
\quad(n=6)\end{array}$ & $\begin{array}{c}\text { Nonbreeding season } \\
\qquad(n=12)\end{array}$ \\
\hline Ejaculate volume $(\mathrm{ml})$ & $1 \cdot 3 \pm 0 \cdot 1$ & $1.6 \pm 0.2$ \\
\hline Sperm concentration $/ \mathrm{ml}\left(\times 10^{-6}\right)$ & $587.5 \pm 71.9$ & $274 \cdot 7 \pm 70 \cdot 2^{*}$ \\
\hline Motility (\%) & $85 \cdot 0 \pm 3 \cdot 1$ & $69.6 \pm 5.8^{*}$ \\
\hline Motility status & $3 \cdot 0 \pm 0.1$ & $2.9 \pm 0.3$ \\
\hline Normal spermatozoa (\%) & $90.4 \pm 1.5$ & $54.7 \pm 7.9^{*}$ \\
\hline \multicolumn{3}{|l|}{ Sperm abnormalities $(\%)$} \\
\hline abnormal acrosome & $5 \cdot 5 \pm 0.5$ & $25 \cdot 1 \pm 5 \cdot 8^{*}$ \\
\hline knobbed acrosome & $0.7 \pm 0.3$ & $6 \cdot 5 \pm 2 \cdot 0^{*}$ \\
\hline damaged apical ridge & $1.8 \pm 0.2$ & $8 \cdot 7 \pm 2 \cdot 3^{*}$ \\
\hline missing apical ridge & $2.6 \pm 0.6$ & $4.4 \pm 1.5$ \\
\hline loose acrosomal cap & $0.5 \pm 0.2$ & $5 \cdot 5 \pm 2 \cdot 0^{*}$ \\
\hline proximal cytoplasmic droplet & $0.8 \pm 0.3$ & $10.9 \pm 3.2^{*}$ \\
\hline distal cytoplasmic droplet & $1.4 \pm 0.4$ & $3 \cdot 3 \pm 0.9$ \\
\hline bent midpiece & $0.3 \pm 0.3$ & $0.7 \pm 0.3$ \\
\hline bent midpiece with droplet & $0.5 \pm 0.4$ & $3.0 \pm 0.8^{*}$ \\
\hline bent tail & $1.1 \pm 0.7$ & $0.9 \pm 0.3$ \\
\hline coiled tail & $0.7 \pm 0.3$ & $1.6 \pm 0.5$ \\
\hline
\end{tabular}

\section{Discussion}

The increased basal and exogenous hormone-stimulated testosterone secretion observed during the breeding season in the territorial impala was similar to that described for sheep (Lincoln, 1977; 
Sanford et al., 1984) and deer (Mirarchi et al., 1978; Van Mourik et al., 1986; Asher et al., 1989; Suttie et al., 1989). Of particular interest was the observation that the GnRH-induced pituitary secretion of LH was attenuated during the breeding season compared to that observed during the nonbreeding season. Yet, despite this reduction in LH secretion during the period of peak sexual activity, the subsequent testosterone response to GnRH or hCG was enhanced compared with that measured during the nonbreeding season. This heightened testicular responsiveness during rut was associated with a doubling in $\mathrm{LH}$ receptor concentrations. As testis volume in these males also was increased 2-fold, the increase in total testicular $\mathrm{LH}$ receptor content would be even greater. Seasonal increases in testicular responsiveness associated with increased $\mathrm{LH}$ receptor binding have been reported in rams (Barenton \& Pelletier, 1983), hamster (Bartke et al., 1987), bank vole (Clethrionomys glareolus; Tahka \& Rajaniemi, 1985), bush rat (Rattus fuscipes; Irby et al., 1984) and mongoose (Herpestes auropunctatus; Soares \& Hoffman, 1982a). The increase in LH receptors in seasonally breeding animals has been related to both increased Leydig cell numbers and $\mathrm{LH}$ receptors per cell (Hochereau-de Riviers \& Lincoln, 1978; Soares \& Hoffman, 1982a; Irby et al., 1984; Tahka \& Rajaniemi, 1985). Thus, in the impala, enhanced steroidogenic activity during rut appears related to an increased functional capacity of the testis (via increased gonadotrophin receptors) rather than to any direct increases in pituitary responsiveness.

The cause of the reduced pituitary responsiveness to GnRH during rut is not known, but similar seasonal changes in GnRH-reduced gonadotrophin secretion have been reported for other ungulates (sheep, Lincoln, 1977; Sanford et al., 1984; deer, Lincoln \& Kay, 1979; Van Mourik et al., 1986; Suttie et al., 1989). Increased pituitary LH levels prior to the onset of the breeding season rather than during the active breeding season have been reported for sheep and deer (Lincoln, 1981) and rock hyrax (Millar \& Glover, 1973). It has been further suggested that the seasonal decline in pituitary $\mathrm{LH}$ concentrations is related to gonadotrophin depletion when pulsatile secretion is maximal (Millar \& Glover, 1973). Alternatively, because testosterone is known to attenuate pituitary responsiveness to GnRH in sheep (Hopkinson et al., 1974), reduced LH release during the breeding season may result from a direct negative feedback of increased serum testosterone secretion. In this study, there was no evidence of pulsatile LH or testosterone secretion in salinetreated animals during the 2-h bleeding period - probably the result of using anaesthetics that block episodic hormone secretion (Clarke \& Doughton, 1983; Peet \& Lincoln, 1977). Thus, it is not possible to speculate on seasonal changes in hormone secretory dynamics between seasons using this experimental protocol. However, the use of a $\mathrm{GnRh}$ challenge clearly demonstrates changes in pituitary function between seasons.

GnRH-induced FSH secretion also decreased during rut similar to that described for LH. In many species, seasonal increases in serum FSH occur before the breeding season onset and are associated with testicular recrudescence rather than the maintenance of spermatogenic activity (Lincoln, 1978; Soares \& Hoffman, 1982b; Sanford et al., 1984). Testicular FSH receptor concentrations were not altered by season, although receptor content increased during rut as a consequence of the increase in testes size. Seasonal increases in FSH receptor content have been reported for the sheep (Barenton \& Pelletier, 1983), hamster (Bartke et al., 1987), bush rat (Irby $e t$ al., 1984) and blue fox (Alopex lagopus; Smith et al., 1985). These receptor changes are probably related to an increase in numbers of receptors per cell rather than to a change in number of cells, as the Sertoli-cell population has been shown to be stable in adult rams and unaffected by season (Hochereau-de Reviers \& Lincoln, 1978).

Overall seminal quality was compromised in impala ejaculates collected during the nonbreeding season, not unlike that described for other seasonal breeders (Lincoln, 1981). Bimonthly evaluations of testicular function have revealed that a number of African antelope species (black wildebeest, Connochaetes gnou, and red hartebeest, Alcelaphus buselaphus; Skinner et al., 1973; and springbok, Antidorcas marsupialis, blesbok, Damaliscus dorcas and greater kudu, Tragelaphus strepsiceros; Skinner, 1971), including impala (Skinner, 1971), produce the fewest epididymal spermatozoa and have the lowest epididymal sperm motility values during the spring (September- 
November). The $\sim 50 \%$ reduction in testes volume observed in the impala during the nonbreeding season also is consistent with reductions in testicular weight and seminiferous tubule diameter reported for other African ungulates (Skinner, 1971; Skinner et al., 1973). The reduction in sperm concentration probably reflects the smaller testes as a correlation between scrotal circumference and sperm production has been observed in domestic cattle (Hahn et al., 1969) and in one other nondomestic ungulate (dorcas gazelle, Gazella dorcas; Howard et al., 1983). Impala electroejaculates collected during the nonbreeding season contained high percentages of spermatozoa with acrosomal defects and cytoplasmic droplets. Similar seasonal changes in ejaculate quality, including spermatozoal abnormalities, have been reported in sheep (Cupps et al., 1960), horse (Van der Holst, 1975) and rhesus monkey (Zamboni et al., 1974). The retention of the cytoplasmic droplet in sperm collected during the nonbreeding season suggests that epididymal function is compromised at this time (Lincoln, 1981). The interaction of pituitary and gonadal hormones is essential for normal spermatogenesis, including the mediation of meiotic events (Lincoln, 1981; Mann \& Lutwak-Mann, 1981). Thus, the reduced testosterone secretion during the nonbreeding season may be contributing to impaired spermatogenesis in the impala.

The observed increases in testicular size, seminal quality and testosterone secretion during the shorter days of autumn (April and May) suggest these animals may be influenced by photoperiod in a similar way to that described for other short-day breeding species, such as sheep (Lincoln \& Davidson, 1977; Sanford et al., 1984) and deer (Mirarchi et al., 1978; Lincoln \& Kay, 1979; Asher et al., 1989). Alternatively, impala breeding activity may be affected by nutritional status, as reported for other nondomestic ungulates (Frazer, 1968; Haigh, 1986). This latter hypothesis is supported by observations that the impala rut generally follows the months of heavy rainfall and increased food quality (Fairall, 1972; Murray, 1982). However, in this case it is difficult to dissociate photoperiodic from nutritional effects, as increased rainfall in the Kruger National Park is accompanied by decreasing photoperiod and changes in season. Nevertheless, as impala breed year-round in areas of abundant food or in captivity (Kayanja, 1969; Jarman \& Jarman, 1974; Haigh, 1986), it is likely that nutrition plays a major role in modulating the reproductive activity of this species.

We thank J. A. Dias, Wadsworth Research Institute, USA, for the FSH antiserum ( $\$ 178)$; L. E. Reichert Jr, Albany Medical College, NY, USA for the ovine LH and FSH for iodination; the NIADDK for the ovine LH and FSH standard preparations; D. Keet, D. Grobler and J. Malan, Kruger National Park, RSA for assistance in all field operations; H. van der Watt and T. A. du Plessis, Iso-Ster Ltd, Kempton Park, RSA for irradiating the serum samples; G. Genovesi, D. Gerstner and B. Rodd, Plum Island Animal Disease Center, NY, USA for providing the facilities for the radioreceptor analyses; M. Nelson and A. Mitchell for excellent technical assistance; and J. Z. Koeser for secretarial support. This study was supported, in part, by Friends of the National Zoo (FONZ), New Opportunities for Animal Health Science (NOAHS) Center and the Ringling Brothers and Barnum and Bailey Circus. Blood samples were collected in full compliance with specific Federal US Fish and Wildlife permits issued to the National Zoological Park, Smithsonian Institution.

\section{References}

Asher, G.W., Peterson, A.J. \& Bass, J.J. (1989) Seasonal pattern of $\mathrm{LH}$ and testosterone secretion in adult male fallow deer, Dama dama. J. Reprod. Fert. 85, 657-665.

Barenton, B. \& Pelletier, J. (1983) Seasonal changes in testicular gonadotropin receptors and steroid content in the ram. Endocrinology 112, 1141-1146.

Bartke, A., Amador, A.G., Chandrashekar, v. \& Klemcke, H.G. (1987) Seasonal differences in testicular receptors and steroidogenesis. J. Steroid Biochem. 27, 581-587.
Bramley, P.S. \& Neaves, W.B. (1972) The relationship between social status and reproductive activity in male impala, Aepyceros melampus. J. Reprod. Fert. 31, 77-81.

Brown, J.L., Stuart, L.D. \& Chakraborty, P.K. (1987) Endocrine profiles, testicular gonadotropin receptors and sperm production in hemi-castrated ram lambs. J. Anim. Sci. 65, 1563-1570.

Brown, J.L. \& Chakraborty, P.K. (1988) Characterization of the effects of clomiphene citrate on 
reproductive physiology in male rats of various ages. Acta endocr., Copnh. 118, 437-443.

Brown, J.L., Wildt, D.E., Raath, J.R., de Vos, V., Howard, J.G., Janssen, D.L., Citino, S.B. \& Bush, M. (1991) Impact of season on seminal characteristics and endocrine status of adult free-ranging African buffalo, (Syncerus caffer). J. Reprod. Fert. 92, 47-57.

Burke, T.J. (1986) Testicular biopsy. In Small Animal Reproduction and Infertility, a Clinical Approach to Diagnosis and Treatment, pp. 140-146. Ed. T. J. Burke. Lea \& Febiger, Philadelphia.

Clarke, I.J. \& Doughton, B.W. (1983) Effect of various anaesthetics on resting plasma concentrations of luteinizing hormone, follicle-stimulating hormone and prolactin in ovariectomized ewes. J. Endocr. 98, 79-89.

Cupps, P.T., McGowan, B., Rahlmann, D.F., Reddon, A.R. \& Weir, W.C. (1960) Seasonal changes in the semen of rams. J. Anim. Sci. 19, 208-213.

Fairall, N. (1972) Behavioural aspects of the reproductive physiology of the impala, Aepyceros melampus (Licht.). Zool. Africana 7, 167-174.

Frazer, A.F. (1968) Reproductive Behaviour in Ungulates. Academic Press, New York.

Hahn, J., Foote, R.H. \& Seidel, G.E. (1969) Testicular growth and related sperm output in dairy bulls. $J$. Anim. Sci. 29, 41-47.

Haigh, J. (1986) Artiodactylids: reproduction. In Zoo and Wild Animal Medicine, pp. 1017-1036. Ed. M. E. Fowler. WB Saunders \& Co., Philadelphia.

Hochereau-de Reviers, M.T. \& Lincoln, G.A. (1978) Seasonal variation in the histology of the testis of the red deer, Cervus elaphus. J. Reprod. Fert. 54, 209-213.

Hopkinson, C.R.N., Pant, H.C. \& Fitzpatrick, R.F. (1974) Release of LH and FSH in the normal intact ram by synthetic LH-RF and the effect of pretreatment with testosterone propionate. J. Reprod. Fert. 39, 135-139.

Howard, J.G., Wildt, D.E., Chakraborty, P.K. \& Bush, M. (1983) Reproductive traits including seasonal observations on semen quality and serum hormone concentrations in the dorcas gazelle. Theriogenology 20, 221-234.

Illius, A.W., Haynes, N.B., Lamming, G.E., Howles, C.M., Fairall, N. \& Millar, R.P. (1983) Evaluation of LH-RH stimulation of testosterone as an index of reproductive status in rams and its application in wild antelope. J. Reprod. Fert. 68, 105-112.

Irby, D.C., Kerr, J.B., Risbridger, G.P. \& de Kretser, D.M. (1984) Seasonally and experimentally induced changes in testicular function of the Australian bush rat (Rattus fuscipes). J. Reprod. Fert. 70, 657-666.

Jarman, P.J. \& Jarman, M.V. (1974) Impala behaviour and its relevance to management. In The Behaviour of Ungulates and its Relation to Management, pp. 871-881. Eds V. Geist \& F. Walther. IUCN New Series, No. 24, Morges, Switzerland.

Kayanja, F.I.B. (1969) The ovary of the impala, Aepyceros melampus, Lichtenstein 1812. J. Reprod. Fert. Suppl. 6, 311-317.

Oberg, E. \& Jones, F.D. (1969) Machinery's Handbook, 18th edn, p. 162. Industrial Press, Inc. New York.

Lincoln, G.A. (1977) Changes in pituitary responsiveness to luteinizing hormone releasing hormone in rams exposed to artificial photoperiod. J. Endocr. 73, 519-527.

Lincoln, G.A. (1978) The temporal relationship between plasma levels of FSH and LH in the ram. J. Reprod. Fert. 53, 31-37.

Lincoln, G.A. (1981) Seasonal aspects of testicular function. In The Testis, pp. 255-302. Eds H. Burger \& D. de Kretser. Raven Press, New York.

Lincoln, G.A. \& Davidson, W. (1977) The relationship between sexual and aggressive behaviour and pituitary and testicular activity during the seasonal sexual cycle of rams, and the influence of photoperiod. $J$. Reprod. Fert. 49, 267-276.

Lincoln, G.A. \& Kay, N.B. (1979) Effects of season on the secretion of $\mathrm{LH}$ and testosterone in intact and castrated red deer stags (Cervus elaphus). J. Reprod. Fert. 55, 75-80.

Mann, T. \& Lutwak-Mann, C. (1981) Testis and testicular semen. In Male Reproductive Function and Semen, pp. 83-138. Eds T. Mann \& C. Lutwak-Mann. Springer-Verlag, New York.

Millar, R.P. \& Glover, T.D. (1973) Regulation of seasonal sexual activity in an ascrotal mammal, the rock hyrax, Procavia capensis. J. Reprod. Fert. Suppl. 19, 203-220.

Mirarchi, R.E., Howland, B.E., Scanlon, P.F., Kirkpatrick, R.L. \& Sanford, L.M. (1978) Seasonal variation in plasma LH, FSH, prolactin, and testosterone concentrations in adult male white-tailed deer. Can. $J$. Zool. 56, 121-127.

Murray, M.G. (1982) The rut of the impala: Aspects of seasonal mating under tropical conditions. $Z$. Tierpsychol. 59, 319-337.

Peet, M.J. \& Lincoln, G.A. (1977) Blockade of episodic gonadotrophin secretion by Immobilon in ovariectomized ewes. J. Reprod. Fert. 50, 97-100.

Sanford, L.M., Howland, B.E. \& Palmer, W.M. (1984) Seasonal changes in the endocrine responsiveness of the pituitary and testes of male sheep in relation to their patterns of gonadotropic hormone and testosterone secretion. Can. J. Phys. 62, 827-833.

Skinner, J.D. (1971) The effect of season on spermatogenesis in some ungulates. J. Reprod. Fert. Suppl. 13, 29-37.

Skinner, J.D., Van Zyl, J.H.M. \& Van Heerden, J.A.H. (1973) The effect of season on reproduction in the black wildebeest and red hartebeest in South Africa. J. Reprod. Fert. Suppl. 19, 101-110.

Smith, A.J., Mondain-Monval, M., Moller, O.M., Scholler, R. \& Hansson, V. (1985) Seasonal variations of $\mathrm{LH}$, prolactin, androstenedione, testosterone and testicular FSH binding in the male blue fox (Alopex lagopus). J. Reprod. Fert. 74, 449-458.

Soares, M.J. \& Hoffman, J.C. (1982a) Seasonal reproduction in the mongoose, Herpestes auropunctatus II. Testicular responsiveness to luteinizing hormone. Gen. Comp. Endocr. 47, 226-234.

Soares, M.J. \& Hofiman, J.C. (1982b) Seasonal reproduction in the mongoose, Herpestes auropunctatus III. Regulation of gonadotropin secretion in the male. Gen. Comp. Endocr. 47, 235-242.

Suttie, J.M., Fennessy, P.F., Corson, I.D., Laas, F.J., Elgar, H.J. \& Lapwood, K.R. (1989) LH and testosterone responses to $\mathrm{GnRH}$ in red deer (Cervus 
elaphus) stags kept in a manipulated photoperiod. $J$. Reprod. Fert. 85, 213-219.

Tahka, K.M. \& Rajaniemi, H. (1985) Photoperiodic modulation of testicular LH receptors in the bank vole (Clethrionomys glareolus). J. Reprod. Fert. 75, 513-519.

Van der Holst, W. (1975) A study of the morphology of stallion semen during the breeding and non-breeding seasons. J. Reprod. Fert. Suppl. 23, 87-89.

Van Mourik, S., Stelmasiak, T. \& Outch, K.H. (1986) Seasonal variation in plasma testosterone, luteinizing hormone concentrations and LH-RH responsiveness in mature, male rusa deer (Cervus rusa timorensis). Comp. Biochem. Physiol. 83A, 347-351.

Wildt, D.E., Bush, M., Howard, J.G., O'Brien, S.J., Meltzer, D., van Dyk, A., Ebedes, H. \& Brand, D.J. (1983) Unique seminal quality in the South African cheetah and a comparative evaluation in the domestic cat. Biol. Reprod. 29, 1019-1025.

Zamboni, L., Conaway, C.H. \& Van Pelt, L. (1974) Seasonal changes in production of semen in freeranging rhesus monkeys. Biol. Reprod. 11, 251-267.

Received 10 December 1990 